\title{
Transformation Products of Emerging Pollutants Explored Using Non-Target Screening: Perspective in the Transformation Pathway and Toxicity Mechanism-A Review
}

\author{
Thodhal-Yoganandham Suman ${ }^{1,2}$, Soo-Yeon Kim ${ }^{3}$, Dong-Hyuk Yeom ${ }^{3}$ and Junho Jeon ${ }^{1,2, *(D)}$ \\ 1 Department of Environmental Engineering, Changwon National University, \\ Changwon 51140, Gyeongsangnam-do, Korea; sumancas2010@gmail.com \\ 2 School of Smart and Green Engineering, Changwon National University, \\ Changwon 51140, Gyeongsangnam-do, Korea \\ 3 Gyeongnam Branch Institute, Korea Institute of Toxicology (KIT), Jinju-si 52834, Korea; \\ sykim@kitox.re.kr (S.-Y.K.); dhyeom@kitox.re.kr (D.-H.Y.) \\ * Correspondence: jjh0208@changwon.ac.kr
}

check for

updates

Citation: Suman, T.-Y.; Kim, S.-Y.;

Yeom, D.-H.; Jeon, J. Transformation Products of Emerging Pollutants

Explored Using Non-Target

Screening: Perspective in the

Transformation Pathway and Toxicity

Mechanism-A Review. Toxics 2022,

10, 54. https://doi.org/10.3390/

toxics10020054

Academic Editor: Ilaria Corsi

Received: 28 December 2021

Accepted: 17 January 2022

Published: 24 January 2022

Publisher's Note: MDPI stays neutral with regard to jurisdictional claims in published maps and institutional affiliations.

Copyright: () 2022 by the authors. Licensee MDPI, Basel, Switzerland. This article is an open access article distributed under the terms and conditions of the Creative Commons Attribution (CC BY) license (https:// creativecommons.org/licenses/by/ $4.0 /)$.

\begin{abstract}
The scientific community has increasingly focused on forming transformation products (TPs) from environmental organic pollutants. However, there is still a lot of discussion over how these TPs are generated and how harmful they are to living terrestrial or aquatic organisms. Potential transformation pathways, TP toxicity, and their mechanisms require more investigation. Non-target screening (NTS) via high-resolution mass spectrometry (HRMS) in model organisms to identify TPs and the formation mechanism on various organisms is the focus of this review. Furthermore, uptake, accumulation process, and potential toxicity with their detrimental consequences are summarized in various organisms. Finally, challenges and future research initiatives, such as performing NTS in a model organism, characterizing and quantifying TPs, and evaluating future toxicity studies on TPs, are also included in this review.
\end{abstract}

Keywords: environmental contamination; transformation products; non-target screening; transformation pathways; toxicity

\section{Introduction}

Concerns about emerging pollutants (EPs) have increased in recent years due to their prevalence in the environment and the potential for deleterious effects on the environment [1-4]. Effluent discharges from industrial wastewater treatment plants (WWTPs), municipal, hospital, sewer overflow / sewer leakage, and surface runoff from agricultural or urban areas can all introduce EPs to the aquatic environment [5-9]. A special focus has been paid to WWTPs due to the relatively frequent release and high contribution of EPs into the environment. Raw influent and treated effluent commonly include EPs at concentrations ranging from $\mathrm{ng} / \mathrm{L}$ to $\mathrm{mg} / \mathrm{L}$ [10-14]. The socioeconomic composition of the population feeding into WWTPs impacts the concentrations and types of EPs in wastewaters. EPs in the water environment have often been accumulated in aquatic organisms and lead to alterations that endanger the sustainability of aquatic ecosystems $[15,16]$.

According to the network of reference laboratories, research centers, and related organizations for monitoring emerging environmental substances (NORMAN), chemicals that are not covered by systematic environmental monitoring programs can be candidates for legislative management in the future due to their deleterious consequences and persistence. Water and wastewater treatment regulatory and implementation agencies assume that so-called priority pollutants account for most human health, environmental, and economic risk, even though they represent only a small proportion of the known and yet-to-be-identified chemical substances [17]. Unlike POPs designated in the Stockholm 
Convention, EPs, including an extensive range of substances, are discussed due to the scarcity of information on their occurrences and potential risks and thus the absence of management plan. Recent studies identified many different kinds of new pollutants, including perfluorinated compounds, artificial sweeteners, pharmaceuticals and disinfection byproducts, hormones and UV filters, and benzotriazoles siloxanes, naphthenic acids, musk fragrances, and TPs [18-20].

Identifying, detecting, and quantifying countless chemicals in the environment are significant hurdles that scientists and policymakers across the globe are now facing. In particular, tracking and recognizing TPs are challenging tasks, mainly due to the difficulty in predicting transformation pathways and the lack of a reference standard for orthogonal confirmation via instrumental analysis. Chromatography coupled with the mass spectrometer technique is the primary method for detecting TPs in the environment and organisms [21-25]. Recent advances in technology have extended the identification and quantification capability. For example, high-resolution mass spectrometry (HRMS) features good mass accuracy, high mass resolving power (greater than 50,000), high picomolar to femtomolar range sensitivity, and good isotopic abundance accuracy $(3-20 \%)[26,27]$. These merits rely on several operational factors, including scan speed, the mass range for an analyte, and ionization efficiency. For analysis of polar organic compounds, including most TPs present in trace amounts, liquid chromatography (LC) connected to HRMS such as time-of-flight (TOF) or Orbitrap type [28] has often been used. A new generation of quadrupole preceding tandem HRMS (e.g., QTOF and QExactive Orbitrap) is capable of highly selective and sensitive analysis for trace pollutants. In addition, the hybrid technique and sophisticated software processing mass spectrum data enables non-target screening (NTS, including suspect screening), which is applicable for the identification of less recognized and/or unknown substances such as TPs [28]. HRMS-based NTS has significantly contributed to a comprehensive understanding of TPs in environments.

Nevertheless, TPs' occurrences and fate are likely insufficient to evaluate the toxicity and environmental risk. TPs are, in many cases, more polar and less hazardous than their parent compounds. Yet, the toxicity and persistence of TPs may vary widely depending on the alteration of molecular structures [24]. Non-mammalian model species have been developed over many years as an alternative to investigating harmful substances, since no toxic compounds can be studied in humans, and a limited number of mammal models are available [29]. Beneficial qualities such as a short lifespan and a lack of need for specialized care led to the selection of these non-mammalian models. The adverse effects of TPs have been studied using various models, including cell lines, earthworms, crustaceans, and fish. To better comprehend the impact of TPs on the larger organism, the findings of studies with model organisms are critical.

The primary goal of this study is to provide a summary of the current level of understanding for the fate of TPs and the ecotoxicological impacts on both terrestrial and aquatic organisms. We highlight how the advancement of precise mass equipment and computer/software tools has led to NTS, an essential component of an integrated approach to TP identification. Finally, we examine some critical features of the advances achieved in understanding the outcome and toxicity of TPs and the difficulties and possibilities of identifying whether these TPs can cause environmental issues in the future.

\section{Transformation Products}

Over the previous century, the industry has generated new chemical products such as agricultural pesticides, pharmaceuticals, plastics, and dyes; unfortunately, they contain a broad spectrum of dangerous and/or persistent compounds extensively occurring in environmental compartments. The synthesized organic compounds can be categorized according to their molecular structure and functional groups (e.g., ethers, acids, alcohols, esters, hydroxyl, alkyl halides, and in each group, amines) [30]. There are a variety of abiotic and biotic processes (e.g., photolysis, hydrolysis, microbial/enzymatic metabolism, and oxidation) that might result in the formation of TPs, including the breakdown of 
the parent compounds (Figure 1) [31-33]. In the case of metabolites (or biochemically transformed products, BTPs), the parent chemical accumulated in biota is often engaged to phase 2 reactions, leading to conjugated forms, which are easily excreted due to the enhanced water solubility [34]. Some TPs are biologically active and are of concern in terms of ecotoxicity [35-37].

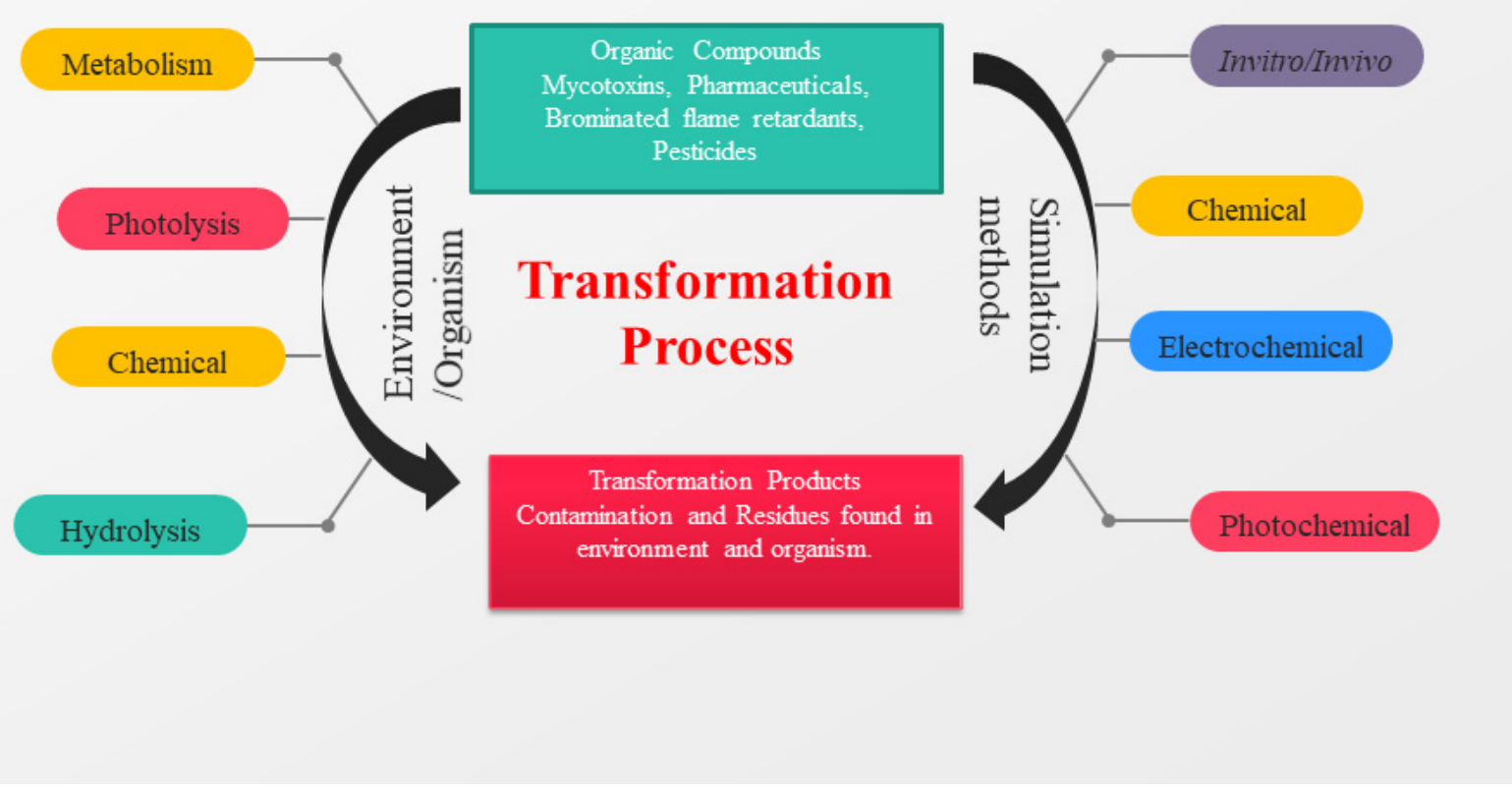

Figure 1. A diagram depicting the transformation processes that occur in organic compounds. General transformation processes in organisms and their environments are represented on the left, while the most frequent simulation approaches are shown on the right.

Unlike other compounds, emerging pollutants have less data on TPs. Specific compounds and their TPs have been identified in waste sources, such as septic systems [38,39], wastewater treatment plants [34,40-42], animal manure [43,44], and lands [45]. Gemfibrozil, ofloxacin, ibuprofen, irbesartan, and venlafaxine were found in wastewater treatment facilities and surface water at concentrations of more than $100 \mathrm{mg} / \mathrm{L} \mathrm{[46].} \mathrm{While} \mathrm{looking} \mathrm{for}$ common fragments, valsartan and its three TPs were identified in waters. O-desmethylvenlafaxine and an oxidized form of gemfibrozil TPs were detected more often than their parent compounds. Some TPs in wastewater treatment facilities were frequently detected compared to the surface waters. Ibuprofen degradation products IbB4, IbSW2, and Ib1 and the TPs of gemfibrozil, GSWB1 were the examples (Figure S1, Table 1). 
Table 1. Pharmaceuticals and metabolites/TPs detected in Effulent waste water and surface water samples after retrospective search in Q-TOF- MS data. (Reprinted from [46]. (Copyright 2016, Elsevier)).

\begin{tabular}{ccc}
\hline & \multicolumn{3}{c}{ Positive Finding (\%) } \\
\hline & $\begin{array}{c}\text { EWW } \\
(\boldsymbol{n}=\mathbf{3 8})\end{array}$ & $\begin{array}{c}\text { SW } \\
(\boldsymbol{n}=\mathbf{1 8})\end{array}$ \\
\hline Irbesartan & 92 & 39 \\
ISW1 & 87 & 6 \\
IB3 & 84 & 22 \\
IB3 & 89 & 22 \\
IB4 & 32 & 11 \\
IB5 & 79 & 22 \\
Valsartan & 79 & 33 \\
Venlafaxine & 87 & 22 \\
VB1a & 92 & 17 \\
VB1b & 92 & 17 \\
V1 & 58 & 6 \\
V2 & 87 & 11 \\
Ofloxacin & 82 & 17 \\
Ibuprofen & 11 & 6 \\
IbSW2a & 16 & 11 \\
IbSW2b & 8 & 0 \\
IbB4 & 34 & 50 \\
Ib1 & 21 & 6 \\
Gemfibrozil & 24 & 22 \\
GSWB1 & 71 & 33 \\
\hline
\end{tabular}

According to previous studies, sulfamethoxazole TPs accounted for up to $86 \%$ of the total load in untreated wastewater [47]. Parent compounds have shown to be more persistent, with TPs accounting for $5 \%$ in treated effluent [48]. The peak area ratios of TPs in wetland were also well recorded in other research [49], with most TPs showing larger peak ratios at the exit point of the wetland compared to the inlet site. Seven TPs were eventually verified using reference standards in the study. At the same time, the identifications of the other TPs achieved high confidence levels by giving diagnostic structural evidence via fragment elucidations and MS/MS database comparisons.

Organic pollutants and their TPs are excreted and may infiltrate environmental systems (Figure 2), including groundwater, soil, sediment, and biota. These matrices might be affected by their occurrences [50-52]. Percussor pollutants such as pharmaceuticals [34,35], pesticides [31,32,53-55], surfactants [33,56,57], hormones [38,58], and personal care products $[36,37]$ have often been found in the environment. When EPs enter the environment, they undergo biological and chemical transformations, resulting in molecular weight variations [59-76] (Table 2). Meanwhile, some TPs have been detected more significantly in the environment than their parents. Thus, the environmental prevalence of synthetic organic compounds might be significantly underestimated if TPs are not considered [77-81]. 

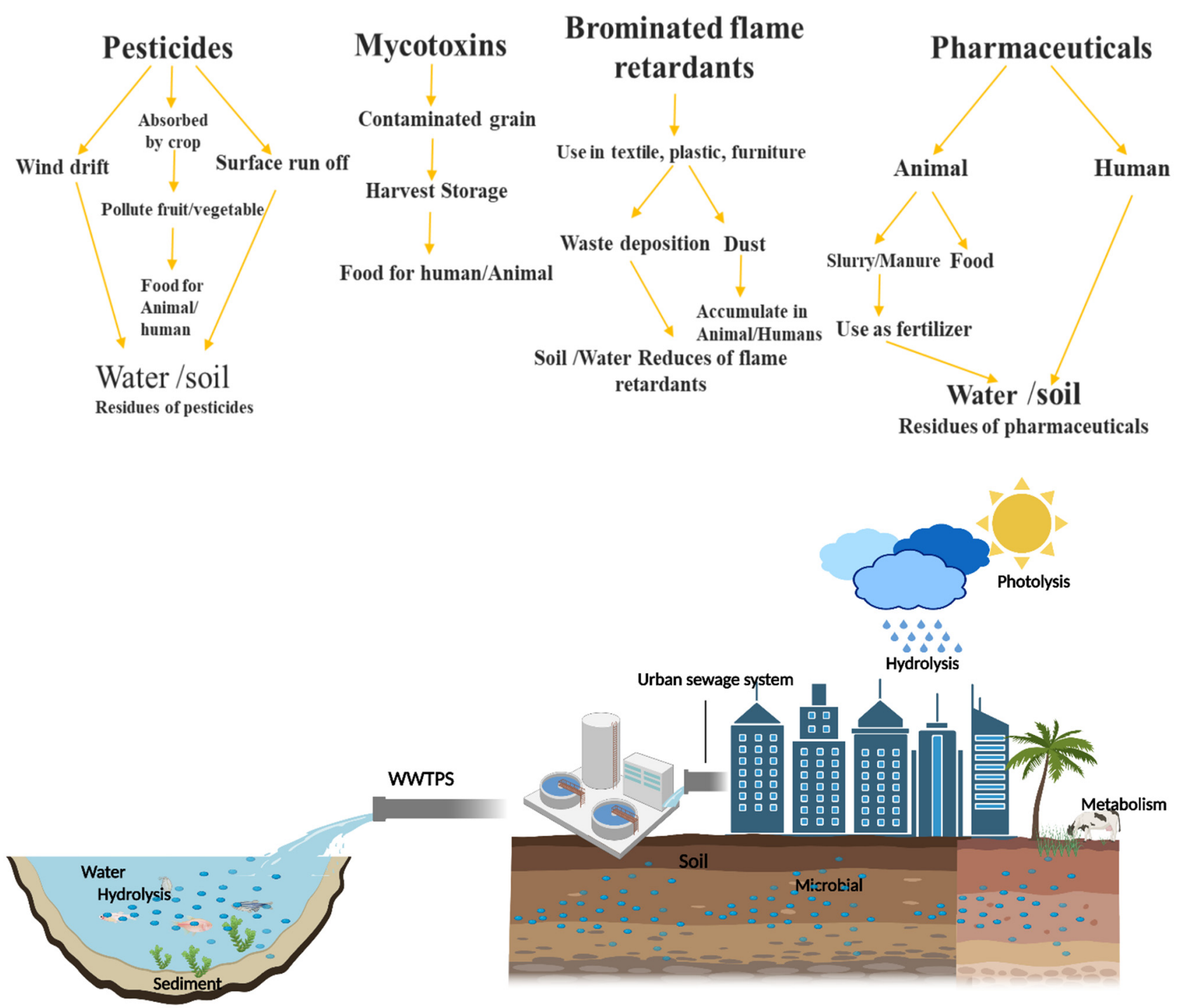

Figure 2. Contaminants and residues of mycotoxins, pesticides, pharmaceuticals, and brominated flame retardants may enter the environment via various routes, including water, sediment, soil, and groundwater. Hydrolysis, photolysis, metabolism, and microbial activity are the critical transformation mechanisms resulting in diverse TP formations that are broadly distributed.

Table 2. Possible biological and chemical transformation reactions and associated mass changes. (Reprinted from [82], Copyright 2021, Elsevier).

$\begin{array}{cccccc}\text { Transformation } & \begin{array}{c}\text { Change in } \\ \text { Molecular } \\ \text { Formula }\end{array} & \begin{array}{c}\text { Mass } \\ \text { Change (Da) }\end{array} & \text { Parent Chemical } \\ \begin{array}{c}\text { loss of nitro } \\ \text { group }\end{array} & -\mathrm{NO}_{2}+\mathrm{H} & -44.9851 & \text { Parent Structure } \\ \text { decarboxylation } & -\mathrm{CO}_{2} & -43.9898 & \text { Roduct Structure }\end{array}$


Table 2. Cont.

\begin{tabular}{|c|c|c|c|c|c|c|}
\hline Transformation & $\begin{array}{l}\text { Change in } \\
\text { Molecular } \\
\text { Formula }\end{array}$ & $\begin{array}{c}\text { Mass } \\
\text { Change (Da) }\end{array}$ & Parent Chemical & Parent Structure & Product Structure & Reference \\
\hline depropylation & $-\mathrm{C}_{3} \mathrm{H}_{6}$ & -42.0468 & Ibuprofen & & & [66] \\
\hline $\begin{array}{l}\text { reductive } \\
\text { displacement } \\
\text { of chlorine }\end{array}$ & $-\mathrm{Cl}+\mathrm{H}$ & -33.9611 & Triclocarban & & & [67] \\
\hline desethylation & $-\mathrm{C}_{2} \mathrm{H}_{4}$ & -28.0312 & Lidocaine & & & [68] \\
\hline dehydration & $-\mathrm{H}_{2} \mathrm{O}$ & -18.0106 & $\begin{array}{l}\text { Hydroxylation } \\
\text { ibuprofen }\end{array}$ & & & [69] \\
\hline $\begin{array}{l}\text { reductive } \\
\text { displacement } \\
\text { of fluorine }\end{array}$ & $-\mathrm{F}+\mathrm{H}$ & -17.9906 & Ciprofloxacin & & & [70] \\
\hline $\begin{array}{l}\text { oxidative } \\
\text { displacement } \\
\text { of chlorine }\end{array}$ & $-\mathrm{Cl}+\mathrm{OH}$ & -17.9662 & Ceftriaxone & & & [71] \\
\hline demethylation & $-\mathrm{CH}_{2}$ & -14.0157 & Naproxen & & & [72] \\
\hline $\begin{array}{l}\text { hydrogenation } \\
\text { reduction }\end{array}$ & 0 & +2.0157 & Carbamazepine & & & [73] \\
\hline $\begin{array}{c}\text { alcohol to } \\
\text { carboxylic acid }\end{array}$ & $-2 \mathrm{H}+\mathrm{O}$ & +13.9792 & $\begin{array}{c}\text { O- } \\
\text { desmethylmetoprolol }\end{array}$ & & & [59] \\
\hline $\begin{array}{l}\text { ketone/aldehyde } \\
\text { formation }\end{array}$ & $-2 \mathrm{H}+\mathrm{O}$ & +13.9792 & $\begin{array}{l}\text { 2,6-di-tert-butyl-4- } \\
\text { methylphenol }\end{array}$ & & & [74] \\
\hline N/S-oxidation & $+\mathrm{O}$ & +15.9949 & $\stackrel{2-}{2-}$ Acetylaminofluorene & & & [75] \\
\hline epoxidation & $+\mathrm{O}$ & +15.9949 & Carbamazepine & & & [73] \\
\hline
\end{tabular}


Table 2. Cont.

\begin{tabular}{|c|c|c|c|c|c|c|}
\hline Transformation & $\begin{array}{c}\text { Change in } \\
\text { Molecular } \\
\text { Formula }\end{array}$ & $\begin{array}{c}\text { Mass } \\
\text { Change (Da) }\end{array}$ & Parent Chemical & Parent Structure & Product Structure & Reference \\
\hline hydroxylation & $+\mathrm{O}$ & +15.9949 & Diclofenac & & & [72] \\
\hline hydration & $+\mathrm{H}_{2} \mathrm{O}$ & +18.0106 & Carbamazepine & & & [73] \\
\hline $\begin{array}{l}\text { methyl to } \\
\text { carboxylic acid }\end{array}$ & $-2 \mathrm{H}+\mathrm{O}_{2}$ & +29.9741 & $\begin{array}{c}\Delta-9- \\
\text { tetrahydrocannabinol }\end{array}$ & & & [76] \\
\hline dihydroxylation & 0 & +31.9898 & Carbamazepine & & & [73] \\
\hline chlorination & $+\mathrm{Cl}-\mathrm{H}$ & 33.9612 & Methylparaben & & & [77] \\
\hline dichlorination & $+2 \mathrm{Cl}$ & 69.9173 & Acetaminophen & & & [78] \\
\hline acetylation & $+\mathrm{C}_{2} \mathrm{H}_{2} \mathrm{O}$ & +42.0106 & Sulfamethazine & & & [79] \\
\hline $\begin{array}{l}\text { hydroxyl } \\
\text { chlorination }\end{array}$ & $+\mathrm{Cl}+\mathrm{OH}$ & 51.9718 & Carbamazepine & & & [78] \\
\hline $\begin{array}{l}\text { oxidative } \\
\text { deamination }\end{array}$ & $-\mathrm{NH}+\mathrm{O}$ & +0.9840 & Amphetamine & & & [80] \\
\hline
\end{tabular}


Table 2. Cont.

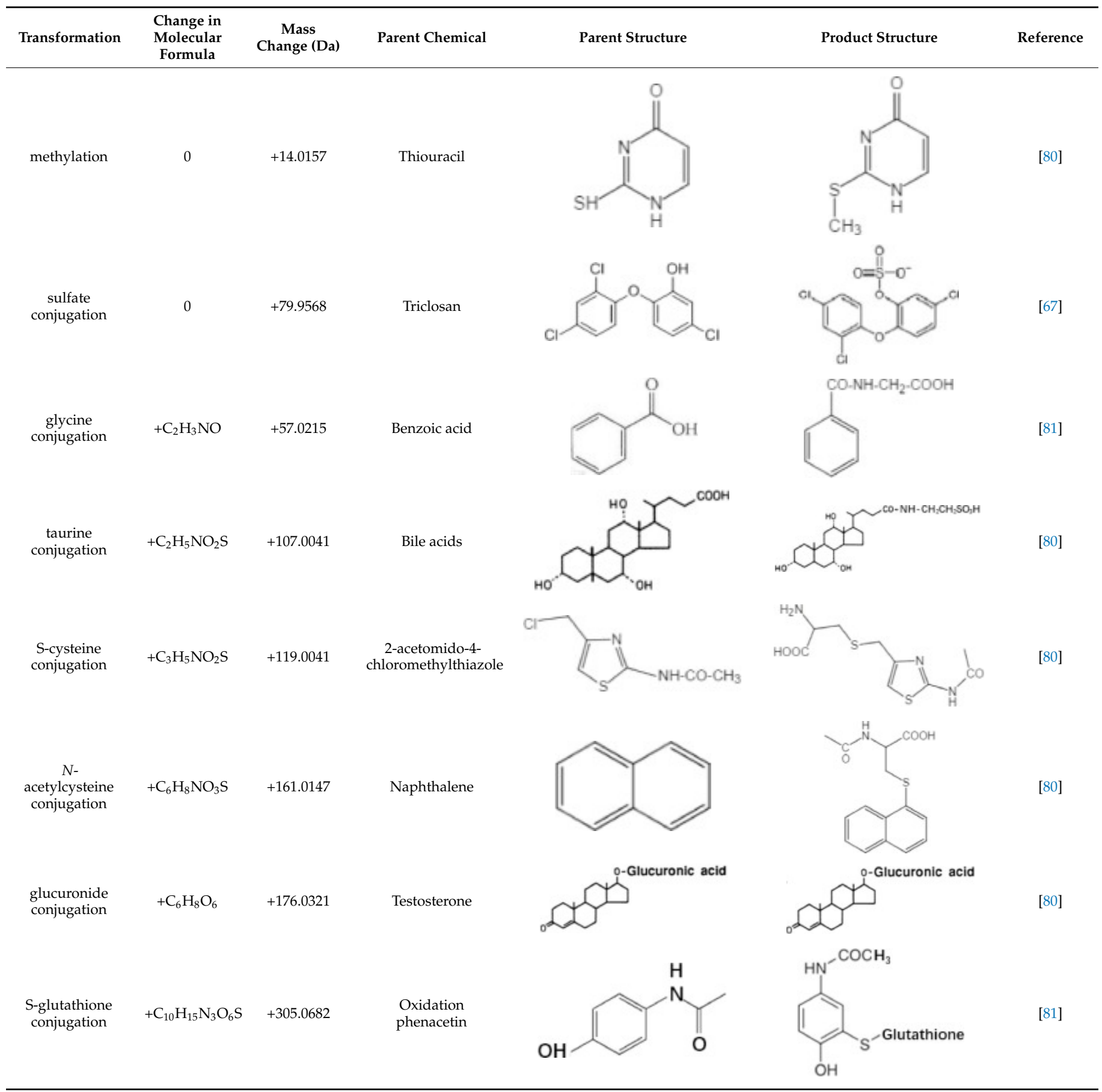

\section{Nontarget Screening}

Detection of highly resolved peaks with HRMS is of the most effective ways to identify novel substances such as TPs [83]. NTS workflows were established in the early 1970s to identify unknown substances. In NTS methods, mass spectrometers and chromatograms are often used. Samples in NTS undergo an extraction procedure to retrieve analytes. Once the analytes have been identified, they may be cross-referenced with databases that provide known elements. The analyte structure would be compared to known compounds and categorized after the analyte components were found. Consequently, there would be a mixture of known and unknown chemical characteristics (Figure 3). The challenge with the HRMS tool is that the instrument generates a lot of spectrum data that should be evaluated 
and exported in a controlled manner. Additionally, the instrument may run in full scan and MS/MS modes simultaneously (i.e., data-dependent/independent MS/MS acquisition), generating even more data to be collected in a single run. As a post step, software-aid processing is required for the acquired spectrum data. The data processing NTS step may be performed using a variety of free and commercial software tools, including:

- XCMS (https:/ / xcmsonline.scripps.edu accessed on: 1 December 2020);

- MZmine (http:/ / mzmine.sourceforge.net/ accessed on: 1 December 2020);

- $\quad$ Non-target, ACD MS/Workbook Suite; and,

- EnviMass (http://www.eawag.ch/forschung/uchem/software/enviMass1 accessed on: 1 December 2020);

- $\quad$ vendors' software, such as TraceFinder/CompoundDiscoverer (Thermo Scientific, Waltham, MA, USA), Profile-Analysis (Bruker, Billerica, MA, USA), MetaboLynx/MassLynx (Waters, Milford, MA, USA), MassHunter (Agilent, Santa Clara, CA, USA), and Data Explorer (Applied Biosystems, Waltham, MA, USA).

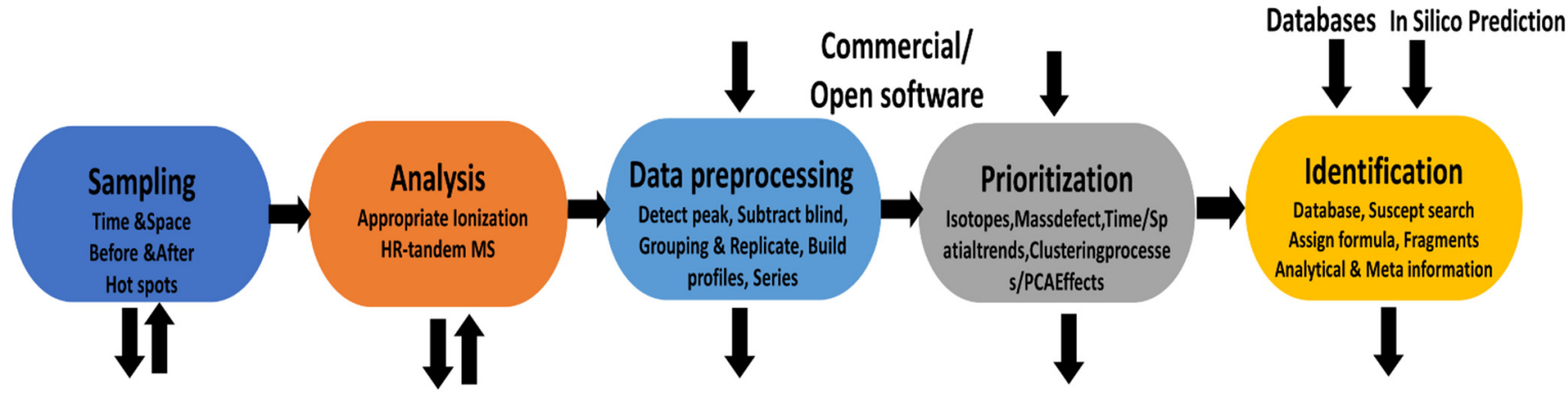

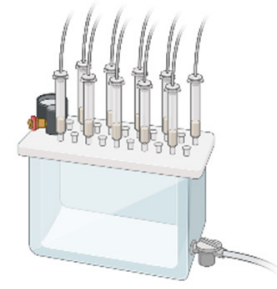

Sample archive

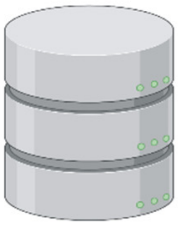

Digital archive

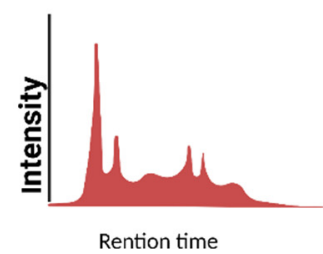

Pollution overview

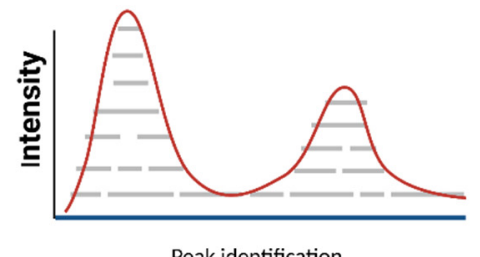

Pattern<smiles>c1ccc2ccccc2c1</smiles>

Structures

Figure 3. Workflow for non-target screening to identify non-targeted peaks with feasible molecular structures.

Choosing the best peaks is the primary step. During this phase, it is critical to compare the sample to control or blank sample to remove irrelevant peaks. Automated processes such as mass calibration, adduct componentization, and isotope peak matching are aimed at ruling out the unnecessary peaks. According to Kind and Fiehn 2007, heuristic filters describe the chemical formula to the exact mass for the hits [84].

It is possible to find potential structures via searching databases such as PubChem, ChemSpider, the NIST or structure creation, and DAIOS database. As a result, the assignment of molecular formula with substructure information can dramatically narrow down the number of candidates in databases and allow easy access to distinctive structures of the hits.

Information on MS/MS fragmentation must be compared to in silico spectral fragmentation from the library to rank the candidate structures. A few mass spectrometer databases provide MS/MS spectrum data, such as:

- MetLin (http://metlin.scripps.edu/index.php accessed on: 1 December 2020). 
- MassBank (http://massbank.ufz.de/MassBank/ accessed on: 1 December 2020); mzCloud (Thermo)

To date, TPs, which are defined as metabolites secreted by organisms and their degradation products formed by biodegradation, photolysis, and/or hydrolysis, have received the most attention in terms of their properties and effects [85-89]. NTS workflows have effectively found the TPs of organophosphate ester from different aquatic organisms [90]. For example, in Daphnia magna (D. magna), Choi et al. (2020) [91] used NTS to identify the TPs of flame retardant triphenyl phosphate. For model organisms, various target analyses have been conducted [92,93]. However, the NTS technique has only been used in a few studies; therefore, there is a lack of knowledge on novel TPs rising concerns in model organisms.

\subsection{Sample Treatment and $Q A / Q C$}

Despite significant advances in implementing QA/QC practices for analytical processes, a substantial nontarget analysis of TPs in organism matrices poses new obstacles. Consequently, an adequate set of QA/QC techniques based on metrological traceability of findings is critical for understanding the reasons for unwanted variances and minimizing them. The analytical laboratory should provide clear criteria for the execution and assessment of each QA/QC activity, identifying the parameter under evaluation and detailing how parameters might be modified to use the set of QA/QC activities properly. The analyst should determine the parameter examined for each QA/QC operation and its excellent decision value based on the study's unique requirements (i.e., objectives, number of samples, matrix, and predicted substances) [94,95]. While implementing all the specified QA/QC steps is not required and is dependent on the project's objectives, implementing specific measures for each analytical stage is necessary to provide accurate findings.

\subsection{Sample Extraction for Non-Target Screening}

For tissue sample extraction, microwave-assisted extraction (MAE), ultrasonic-assisted extraction (UAE), Quick, Easy, Cheap, Effective, Rugged, and Safe (QuEChERS), and pressurized liquid extraction (PLE) have been applied in TP studies (Table S1).

\subsubsection{Quick, Easy, Cheap, Effective, Rugged, and Safe}

Using the QuEChERS approach, minimal solvent consumption, fast extraction, and effective clean-up can be achieved with minimized cost [96]. In addition, it is highly customizable, thus becoming a popular pretreatment method for various biota samples. Analyte characteristics, matrix composition, and analytical method influence efficacy [96]. In general, following a salting-out extraction with solvent (e.g., methanol, acetonitrile, etc.), the QuEChERS method employs a dispersive solid-phase extraction (d-SPE) to reduce matrix effects. An example is the following. Tests of QuEChERS for the extraction of diclofenac and its TPs in bivalves were conducted by Daniele et al. (2016) [97]. A $50 \mathrm{~mL}$ polypropylene centrifuge tube was used to weigh a $100 \mathrm{mg}$ aliquot of homogenized and freeze-dried sample. Extracts of the target analytes were spiked up to $200 \mathrm{mg} / \mathrm{L}$ and diclofenac-d4 $(100 \mathrm{mg} / \mathrm{L})$ in a methanolic mixture, and the solvent was evaporated under a moderate stream of nitrogen for method development. The dry extract was mixed with $5 \mathrm{~mL}$ of water to aid in the salting-out extraction process. It was then mixed with $10 \mathrm{~mL}$ of acetonitrile (ACN) and $200 \mathrm{~mL}$ of heptane and vortexed for $15 \mathrm{~s}$. Then, acetate salt was added, vigorously agitated for $10 \mathrm{~s}$, and vortexed for $20 \mathrm{~s}$. The homogenate was centrifuged for $3 \mathrm{~min}$ at 10,000 rpm to remove the acetate salt. The $6 \mathrm{~mL}$ of ACN was transferred to a $10 \mathrm{~mL}$ glass tube. To keep the analytes from evaporating, $200 \mathrm{~mL}$ of DMSO was added with a moderate stream of nitrogen used to evaporate $\mathrm{ACN}$. As a final step, the remaining DMSO solution was mixed with $50 \mathrm{~mL}$ of ${ }^{13} \mathrm{C}$ phenacetin $(1 \mathrm{mg} / \mathrm{L}$ in $\mathrm{ACN})$ (Figure S2). Quantitative analysis for the residue was carried out using LC-MS/MS. 


\subsubsection{Microwave-Assisted Extraction}

Two different microwave systems, i.e., closed extraction vessels/multi-mode microwave ovens and 'open' focused microwave ovens, have been used in the laboratory for extraction. The most often utilized systems today are closed vessel-like systems (Figure S3), in which the extraction efficiency is determined by applied temperature and pressure. MAE minimizes sample consumption and extraction time by providing a high throughput extraction. In certain circumstances, replacing the extraction phase with water instead of an organic solvent resulted in a more effective extraction [98]. The extraction efficiency was influenced by the solvent's volume and properties, the irradiation period, and microwave power [99]. The target contaminants would decompose due to the high microwave power and lengthy irradiation [100]. Wang et al. (2012) [101] suggested a technique for determining nine steroid hormones in fish tissues based on MAE. Under the influence of microwave radiation, the hormones were extracted with acetonitrile and water. The extract was then separated with ammonium acetate into an acetonitrile phase. The target analytes in the phase were concentrated and analyzed using LC-MS/MS. The recovery values for the method were $78.9-94.3 \%$.

\subsubsection{Pressurized Liquid Extraction}

PLE is a simple and comprehensive extraction process that enables quantitative recoveries with minimal effort on method development. A general procedure is as follows. The cell is put on the carousel once the sample has been entered and mixed with the inert substance. The sample cell is rotated on the carousel before transferring to the oven and immediately sealed under pressure. The cell is then filled with solvent and held in the range for a user-defined time at a persistent pressure and temperature. After collecting the extracted analytes in a vial, the cell is washed and purged with nitrogen gas. These phases form a cycle. The overall extraction time is, in general, 15-45 min. PLE increases the extraction of contaminants from solid materials using standard solvents at raised pressure. It may result in a large percentage of matrix interference being extracted [102]. Pressurized hot water extraction offers an alternative as an ecologically gentle approach [103].

\subsubsection{Ultrasonic-Assisted Extraction}

The UAE extraction process includes homogenizing, freeze-drying, sieving, centrifuging, ultrasonication, and clean-up processes [104]. UAE is a fast and efficient way to extract natural chemicals and contaminants from food and environmental samples, with extraction efficiency equivalent to traditional methods [105]. The UAE approach is a low-cost alternative to contemporary extraction procedures that are simple and may be employed with any solvent. Dorival-Garc'a et al. (2013) explored the productivities of PLE, UAE, and MAE techniques and identified that the methods had similar extraction times, with PLE and MAE providing the best extraction yield [106]. The proposed UAE is an alternative because it is simple to employ, has equal solvent volumes, and has similar precision and sensitivity. Wilkinson et al. (2007) compared the MAE and UAE methods to build a methodology for determining 13 chemicals in aquatic plants and benthic organisms. The UAE-SPE technique offered the best results [89]. Qu et al. (2017) used UAE to minimize extraction time and enhance extraction efficiency to analyze amide herbicide residues in fish [105].

\section{Transformation Pathway in a Model Organism}

In vitro and in vivo metabolic processes may transform organic pollutants into highly reactive metabolites. The principal biotransformation routes accompany reduction, oxidation, and/or hydrolysis during the phase I reaction. In contrast, the phase II reaction mainly features conjugation reactions. Phase II reactions are biosynthetic, as active enzymes connect the metabolite produced by phase I responses to an endogenous polar molecule, resulting in a conjugate. Many endogenous compounds with high polarity (e.g., sugar, amino acids, sulphates, etc.) are used in conjugation, and the resultant conjugates are mostly ionized and highly water soluble. Furthermore, specialized active transport systems 
identify the moieties employed for conjugation, assisting translocation across plasma membranes and increasing the excretion rate $[107,108]$. The endoplasmic reticulum, lipoprotein membranes stretching from mitochondria and nucleus to the plasma membranes of cells, are the primary sources of phase I enzymes in cells. As lipophilic substances preferentially diffuse into lipid membranes the presence of phase I enzymes in lipid membranes has crucial implications for biotransformation [109].

Phase I reactions are more typically related to the production of reactive and more hazardous metabolites; yet, phase II processes, as well as combinations of phase II and phase I processes, may be considered an intoxication procedure [110,111]. However, there is evidence that metabolites of pollutants such as tetrabromobisphenol-A, trenbolone, triclosan, and bisphenol A retain the bioactive moieties and preserve inherent toxicity comparable to the parent compound [112-114]. Methylation in biological systems can produce hydrophobic and bioaccumulative metabolites, often observed in fungus, plants, and bacteria [115]. Compound biotransformation studies are vital to understand the reactivity and toxicity of organisms. Bioaccumulation and toxicity of organic pollutants are heavily influenced by biotransformation, while this process is still poorly understood for emerging contaminants [116]. There have been limited investigations for TPs of EPs in specific organisms, as follows.

\subsection{Algae}

Cymbella sp. were studied for their ability to biotransform triclosan. The results demonstrated that triclosan and its potential hazardous metabolites had a high toxic impact on Cymbella sp., with $72 \mathrm{~h} \mathrm{EC_{50 }}$ of $324.9 \mathrm{mg} / \mathrm{L}$. In diatom cells, 11 metabolites were found and with potential degradation pathways. The transformative reactions of triclosan in Cymbella sp. included methylation, hydroxylation, amino acids conjunction, dichlorination, and glucuronidation, which resulted in biologically active products (e.g., methyl triclosan) and conjugation products (e.g., or oxaloacetic acid conjugated or triclosan glucuronide) [117].

\subsection{Freshwater Crustaceans}

Biotransformation pathways in freshwater crustaceans have been little understood, except in a study using Gammarus pulex (G. pulex) and Daphnia magna (D. magna). For 24 h, G. pulex and D. magna were exposed to a modest dose of biocides and pharmaceuticals and sacrificed to identify their metabolites. Each species produced 25 and 11 metabolites, respectively, for terbutryn, irgarol, venlafaxine, and tramadol, mainly via oxidation and conjugation reactions. Affinity in the synthesis of metabolites, such as oxidation and demethylation products, were found for venlafaxine and tramadol, which have an identical backbone structure. Tramadol and venlafaxine were oxidized the amine or cyclic C-H bond, while irgarol and terbutryn were oxidized at the terminal methyl group (MTE258B, MIR270B, MIR270A, MTE258A, and MIR286) (Figure 4) [118]. In Gammarus pulex (G. pulex) and Hyalella azteca (H. azteca), Fu et al. (2020) found a substantial pathway for diclofenac metabolism [119]. The LC-HRMS/MS data collected from the test species were used to identify metabolites utilizing NTS procedures. As a result, 281 metabolites were identified based on the isotopic signature of chlorine $(\mathrm{Cl})$. H. azteca and G. pulex had nine distinct diclofenac metabolites. 
R1

R2

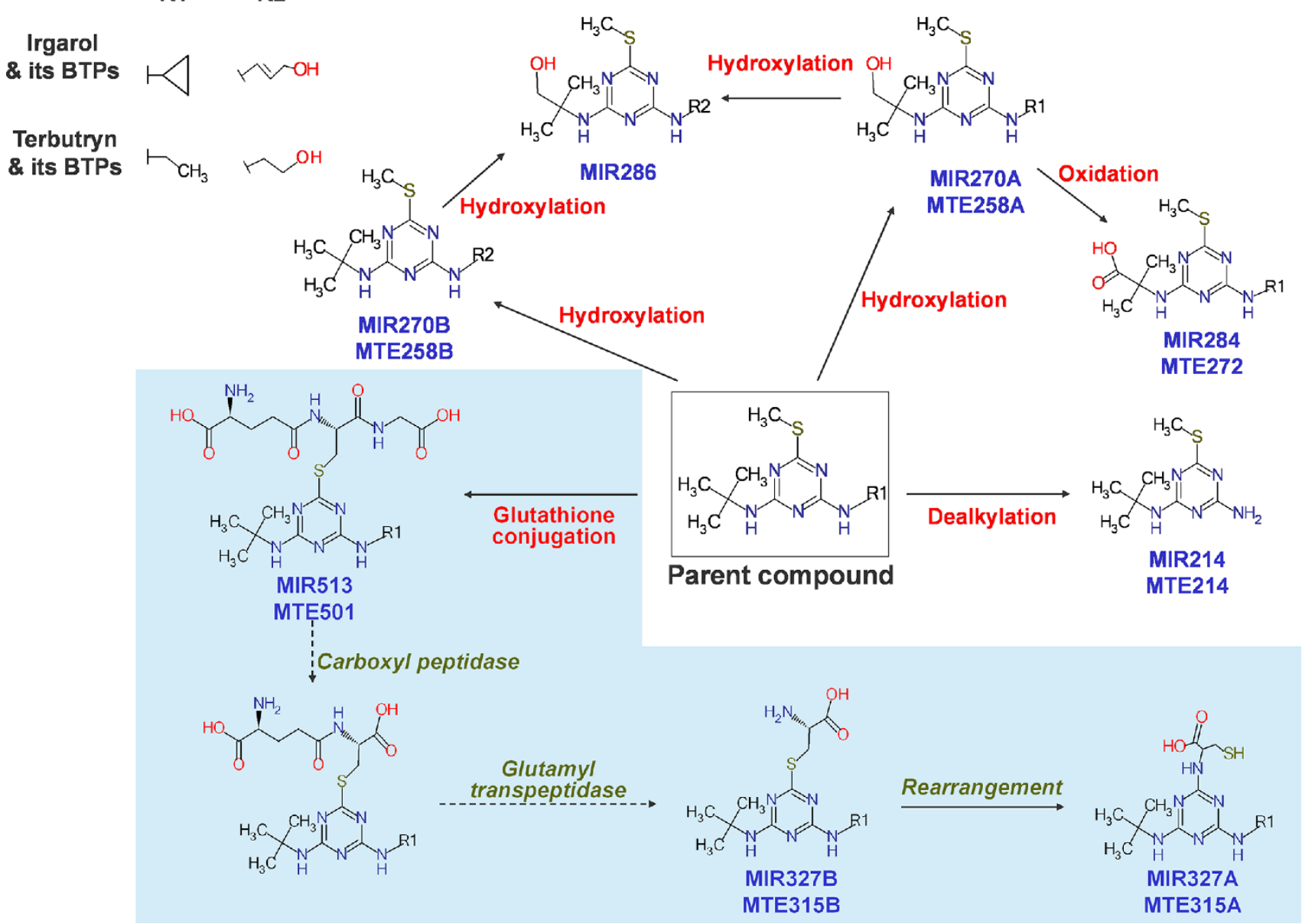

Figure 4. Proposed biotransformation pathways of irgarol and terbutryn in freshwater crustaceans. Note that R2 is the hydroxylated moiety of R1. The sky-blue shaded area indicates a pathway including glutathione conjugation followed by subsequent reactions to form cysteine conjugates, reported for the first time in the test organisms. (Reprinted from [118], Copyright 2013, ACS).

\subsection{Fish}

Metabolites of diclofenac were also identified in vertebrates. Oncorhynchus mykiss, have produced hydroxylate and conjugate of diclofenac with glucuronic acid, glutathione, and sulfate. Other EPs, including pharmaceuticals (propranolol, carbamazepine) and insecticides (diazinon, azoxystrobin, and fipronil), were found in the S9 extract of trout liver [120]. It was revealed that each of the five parents had ten distinct metabolites. The primary metabolic mechanisms were oxidation, dealkylation, S-oxidation, and epoxidation. The formation of metabolites for fipronil and diazinon was enhanced as increasing carbamazepine concentration in the binary exposure, whereas the transformation kinetic for propranolol and azoxystrobin was decreased. Toxic diazoxon and less toxic pyrimidinol, among significant diazinon metabolites, were promptly formed by S9 after the binary exposure with carbamazepine.

\subsection{Earthworm}

High-production-volume surfactants, also known as polyfluoroalkyl phosphate esters (PAPs), are employed in the packaging industry and food contact paper. PAPs can transform into perfluoroalkyl carboxylic acids, which are highly bioaccumulative and persistent in the environment, although their fate remains unknown in terrestrial species. To investigate biotransformation, Zhu et al. (2021) subjected M. guillelmi to soil contaminated with 6:2 fluorotelomer phosphate diester (6:2 diPAP). According to in vitro desorption 
tests [121], 6:2 diPAP desorbed from soil was considerably accumulated in gut digesting fluid. Phase I products included perfluoropentyl propanoic acid, perfluorohexanoic acid, 2-perfluorohexyl ethanoic acid, perfluoropentanoic acid, and perfluoroheptanoic acid, all of which confirmed that $\beta$ and $\alpha$ oxidation occurred in earthworms. As a phase II product, 6:2 fluorotelomer alcohol-sulfate conjugate was found at unusually high quantities in earthworms for the first time, which may be the principal mechanism by which earthworms remove 6:2 diPAP.

\subsection{Human Cell Lines}

Using human skin subcellular fractions, the in vitro metabolism of 2-ethylhexyl-2,3,4,5tetrabromobenzoate (EH-TBB) and a mixture of Bis(2-ethylhexyl) tetrabromphthalate (BEHTEBP), EH-TBB, and triphenyl phosphate was evaluated for the first time. Analysis of EHTBB and THP utilizing UPLC-Q-Exactive Orbitrap identified the two primary metabolites, tetrabromobenzoic acid (TBBA) and diphenylphosphate (DPhP). It was assumed that CYP450 enzymes were responsible for the dermal biotransformation of TPhP and EH-TBB, but no stable metabolites were found for BEH-TEBP [122].

\section{Toxicity Effect of TPs on the Model Organism}

\subsection{Potential Bioactivation Mechanisms}

Biotransformation may undergo a two-step process. In the first phase, including reduction, oxidation, and/or hydrolysis, the enzymes interact with the EPs and convert them into water-soluble metabolites, in many cases facilitating excretion from the body [123-125]. The biotransformation process generates a variety of intermediate and final metabolites that might result in any of the following outcomes: toxicity, inertness in the body, or safe elimination [125]. Cytochrome P 450 group enzymes CYP1 are active in the first step of EPs biotransformation [123]. There must be an equilibrium between the generation of oxygen atoms and other natural processes such as biotransformation to avoid any unwanted consequences. In phase II processes, metabolites generated in phase I become more water-soluble. Glutathione-S-transferase aids in phase II conjugation processes with glutathione (GST). Antioxidant protection is provided by this enzymatic activity [126]. Phase I metabolites may induce cytotoxicity if they do not undergo the phase II procedure. Due to biotransformation, cell death is caused when the hazardous compounds produced in phase I surpass the organism's ability to conjugate them via phase II (Figure 5) [127]. The CYP1A enzymes produce a majority of the biotransformation products. Figure 5 shows the balance of activities of phase I and phase II enzymes, which define the type and effects of the metabolites generated in the biotransformation process, as the process of detoxification or toxification is depicted.

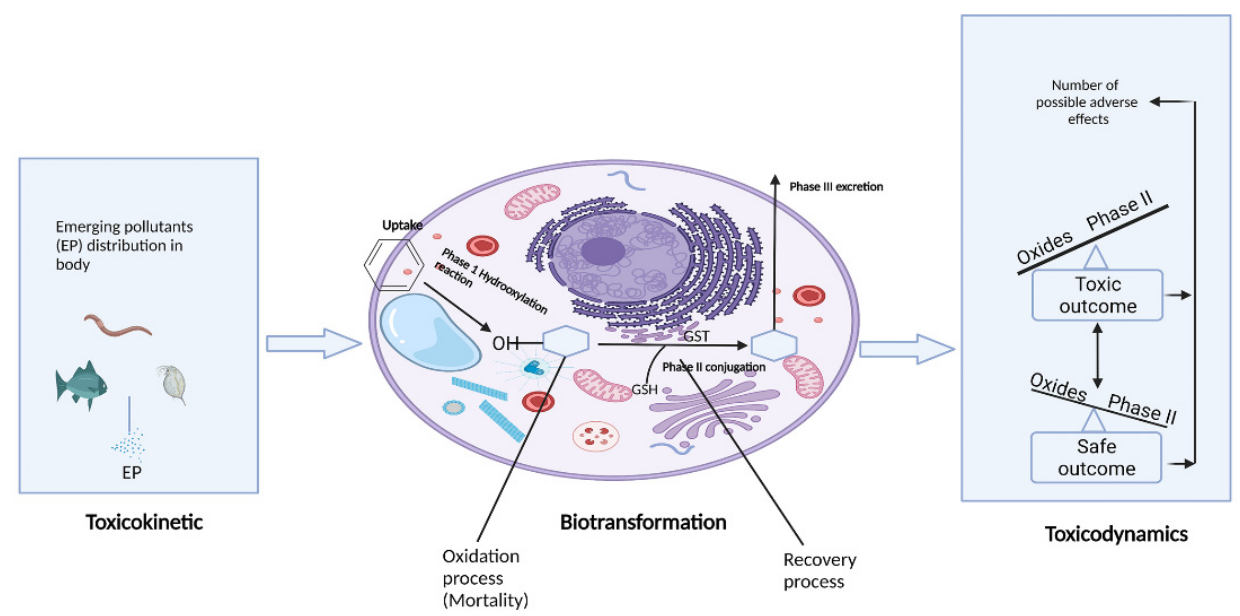

Figure 5. Schematic biotransformation processes result either in toxic or safe products. 


\subsection{Cases for the Formation of Toxic TP}

TPs formed by photoinduced degradation of carbamazepine (e.g., acridine, acridone) have been evaluated for toxicity [128]. Toxic effects reached their maximum for Pseudokirchneriella subcapitata (P. subcapitata) and Vibrio fischeri (V. fischeri). Exposure of D. magna to mixed TPs resulted in immobility after $45 \mathrm{~min}$. Based on estimated $\mathrm{EC}_{50}, \mathrm{NOEC}$, and LOEC, the $\mathrm{EC}_{50}$ for D. magna was $0.71 \mathrm{mg} / \mathrm{L}$ for acridine and $1.49 \mathrm{mg} / \mathrm{L}$ acridone, but the NOEC value for carbamazepine was $30 \mathrm{mg} / \mathrm{L}$ for this species. Acridine was found to be the most hazardous to algae $\left(\mathrm{EC}_{50}=0.61 \mathrm{mg} / \mathrm{L}\right)$ and $V$. fischeri $\left(\mathrm{EC}_{50}=5.34-6.90 \mathrm{mg} / \mathrm{L}\right)$ in the experiments [128]. Grabarczyk et al. (2020) also found that carbamazepine-10,11-epoxide was still harmful to diverse organisms compared to the parent. At $100 \mathrm{mg} / \mathrm{L}$, the luminescence inhibition rate of $V$. fischeri by Carbamazepine-10,11-epoxide was 30\%, whereas the effect was $42 \%$ for carbamazepine. Lemna minor (L. minor) showed similar responses to the epoxide TP and the parent at $50 \mathrm{mg} / \mathrm{L}$ (the epoxide inhibits growth by $32 \%$ and carbamazepine by $49 \%)$. Both were critical to the growth of green algae (48\%). Similar inhibitions were observed for R. subcapitata $(15 \%)$ and L. minor $(11 \%)$ exposed to $10,11-$ dihydro-10-hydroxycarbamazepine. On the other hand, for D. magna, both metabolites of carbamazepine were ineffective, while $24 \%$ of the exposed species to the parent was found to be immobilized [92].

Boillot et al. (2015) investigated the internal concentrations of carbamazepine and oxcarbazepine-10-hydroxy-10,11-dihydrocarbamazepine in biota. After the exposure of Mytilus galloprovincialis to the chemicals for a week, concentrations in media and biota were measured and evaluated for bioconcentration. According to the evaluation, 10hydroxy-10,11-dihydrocarbamazepine showed slightly higher bioconcentration factors than carbamazepine. Carbamazepine-10,11-epoxide and acridine accumulated in the mussel following the exposure. Both chemicals were found in the digestive glands and gills. Acridine was also detected in mantels and measured in digestive glands. This might imply that metabolites can be accumulated in organisms due to direct uptake of the chemical from the media and/or as a resultant of metabolization from the parent [129].

Similarly, carbamazepine was found in fish after $48 \mathrm{~h}$ of exposure in the study of Valdés et al. (2016) [130]. The gills and muscle of J. multidentata contained 2-hydroxycarbamazepine (48 to $107 \times 10^{-6} \mathrm{mg} / \mathrm{g}$ wet weight), while the epoxide TP $\left(41 \times 10^{-6}\right.$ and $60 \times 10^{-6} \mathrm{mg} / \mathrm{g}$ wet weight) was also found. It is indicated that exposed organisms biotransform carbamazepine and accumulate at similar concentrations. Another study provided information on the TPs of $\beta$-blockers and their toxicity. The harmful effects of propranolol investigated on B. calyciflorus and P. subcapitata exposed at concentrations from 1 and $10 \mathrm{mg} / \mathrm{L}$. The findings for both species demonstrated that the irradiated sample had a greater $\mathrm{EC}_{50}$ value (lower toxicity) than the parent compounds at each stage of the experiment $(6,24,48 \mathrm{~h})$. During photolysis, the toxicity was decreased by 1.8 to 3 times [131]. The opposite findings were observed in research of photodegradation products of metoprolol and atenolol [132]. Their photo-TPs had a greater level of toxicity than the parent compound. A significant increase in luminescence inhibition of $V$. fischeri was seen after 16 and $32 \mathrm{~min}$ of metoprolol and atenolol irradiation (Toolaram et al. (2017)).

\section{Challenges and Perspectives for TP Study}

The TPs relevant literature has demonstrated a growing requirement for realistic methodologies to examine the ecotoxicity of TPs. More research is required on the effects, interactions, uptake, and translocation of TPs in organisms due to the rising manufacture of pharmaceuticals, insecticides, and industrial chemicals (e.g., organophosphate flame retardants). One of the main focuses of this review is on how NTS has been used in the model organism, TPs pathway, and toxicity effects. In terms of the ecological consequences of TPs, a number of studies revealed a wide range of outcomes showing increased or reduced toxicity on model species. TP formations in biota are primary consequences of phase I and phase II reactions after the parent molecule is introduced into the organism. At this step, the parent chemical goes through numerous phases of oxidation, hydrolysis, and enzymatic reaction, all of which might influence the TP structure and toxicity. The 
transformation route has been found to enhance or reduce ROS production, survival rate, and bioavailability of TPs in model organisms in previous research.

Furthermore, the hypothesized route has yet to be defined as having a direct influence on the toxicological effects of TPs. Thus, more research should be carried out to determine the impact of TPs. A reliable model must be developed to define and assess TPs with a live organism. As a prerequisite, it is critical to identify as many TPs as possible with reliable information on the chemical structures. Currently, most research relies on target screening for identification, while a few studies have been performed on the unknown TPs using NTS in the absence of reference standards. Even though the identification confidence is not always reliable, efforts and trials to find novel TPs must be continued. As a helpful tool, the software-aid approach can predict the transformation products and pathways [124-126]. In parallel, ecotoxicology investigations should also include NTS for their potential significance in the characterization of unknown TPs and their toxicological consequences.

HRMS, combined with advanced hardware and software, has helped detect unknown migrants from emerging contaminants. Since ESI is the most extensively utilized ionization source, a significant trend toward using HRMS in LC for non-targeted analysis has been noticed in recent years. The developing field of NTS is characterized by both a very complicated scientific setting and a fundamental methodological framework. Each stage of the process in this discipline presents considerable obstacles requiring analytical improvement. Tissue samples need different methods and procedures for other environmental samples such as water and sediments. Efforts to obtain improved consolidation and comparability of data gathered from multiple studies, particularly for use in regulatory and policy support contexts, need a strict harmonization approach. However, to sustain its potential for discovery and exploratory study, this expanding area needs a high degree of adaptability. A combination of LC-HRMS and GC-HRMS is necessary to cover many EPs and their numerous TPs, requiring high-level equipment and extensive technical competence.

On the other hand, to handle the complexity of NTS data, it is essential to use cuttingedge computational tools, many of which are still in development. Furthermore, analytical techniques combined with informatic skills must be practically implemented to expand knowledge on TPs and characterize both TPs and the parent pollutants.

Supplementary Materials: The following are available online at https:/ / www.mdpi.com/article/ 10.3390/toxics10020054/s1, Figure S1: The contaminants selected and their metabolites/TPs in different EWW samples; Figure S2: The diagram of separation process of diclofenac and transformation product; Figure S3: (A) Schematic view for a closed-vessel MAE system and (B) Commercial MAE instrument from Milestone and Carousel with 40 positions; Table S1 Summary for sample extraction method.

Author Contributions: T.-Y.S.: Conceptualization, Investigation, Writing-Original review, Methodology, Validation, Visualization, Software. S.-Y.K.: Data curation, Formal analysis. D.-H.Y.: Data curation, Formal analysis, Investigation. J.J.: Conceptualization, Funding acquisition, Project administration, Writing-Review \& editing. All authors have read and agreed to the published version of the manuscript.

Funding: This work was supported by the Korea Environment Industry and Technology Institute (KEITI) through "The Chemical Accident Prevention Technology Development Project" funded by the Korea Ministry of Environment (MOE) (project number: 2016001970002).

Institutional Review Board Statement: Not applicable.

Informed Consent Statement: Not applicable.

Data Availability Statement: As this a review article, the data supporting the results can be found in the respective references in the manuscript.

Acknowledgments: Graphic design $(2,3,5)$ supplemented by BioRender.

Conflicts of Interest: The authors declare no conflict of interest. 


\section{References}

1. Verlicchi, P.; Zambello, E. Pharmaceuticals and personal care products in untreated and treated sewage sludge: Occurrence and environmental risk in the case of application on soil-A critical review. Sci. Total Environ. 2015, 538, 750-767. [CrossRef] [PubMed]

2. Ferrari, B.; Paxéus, N.; Giudice, R.L.; Pollio, A.; Garric, J. Ecotoxicological impact of pharmaceuticals found in treated wastewaters: Study of carbamazepine, clofibric acid, and diclofenac. Ecotoxicol. Environ. Saf. 2003, 55, 359-370. [CrossRef]

3. Verlicchi, P.; Al Aukidy, M.; Zambello, E. Occurrence of pharmaceutical compounds in urban wastewater: Removal, mass load and environmental risk after a secondary treatment-A review. Sci. Total Environ. 2012, 429, 123-155. [CrossRef] [PubMed]

4. Al Aukidy, M.; Verlicchi, P.; Jelic, A.; Petrovic, M.; Barcelò, D. Monitoring release of pharmaceutical compounds: Occurrence and environmental risk assessment of two WWTP effluents and their receiving bodies in the Po Valley, Italy. Sci. Total Environ. 2012, 438, 15-25. [CrossRef]

5. Wolf, L.; Zwiener, C.; Zemann, M. Tracking artificial sweeteners and pharmaceuticals introduced into urban groundwater by leaking sewer networks. Sci. Total Environ. 2012, 430, 8-19. [CrossRef]

6. Yi, X.; Tran, N.H.; Yin, T.; He, Y.; Gin, K.Y.H. Removal of selected PPCPs, EDCs, and antibiotic resistance genes in landfill leachate by a full-scale constructed wetlands system. Water Res. 2017, 121, 46-60. [CrossRef]

7. Launay, M.A.; Dittmer, U.; Steinmetz, H. Organic micropollutants discharged by combined sewer overflows-characterisation of pollutant sources and stormwater-related processes. Water Res. 2016, 104, 82-92. [CrossRef]

8. Chee-Sanford, J.C.; Mackie, R.I.; Koike, S.; Krapac, I.G.; Lin, Y.F.; Yannarell, A.C.; Maxwell, S.; Aminov, R.I. Fate and transport of antibiotic residues and antibiotic resistance genes following land application of manure waste. J. Environ. Qual. 2009, 38, 1086-1108. [CrossRef]

9. Sidhu, J.P.; Ahmed, W.; Gernjak, W.; Aryal, R.; McCarthy, D.; Palmer, A.; Kolotelo, P.; Toze, S. Sewage pollution in urban stormwater runoff as evident from the widespread presence of multiple microbial and chemical source tracking markers. Sci. Total Environ. 2013, 463, 488-496. [CrossRef]

10. Behera, S.K.; Kim, H.W.; Oh, J.E.; Park, H.S. Occurrence and removal of antibiotics, hormones and several other pharmaceuticals in wastewater treatment plants of the largest industrial city of Korea. Sci. Total Environ. 2011, 409, 4351-4360. [CrossRef]

11. Tran, N.H.; Hu, J.; Ong, S.L. Simultaneous determination of PPCPs, EDCs, and artificial sweeteners in environmental water samples using a single-step SPE coupled with HPLC-MS/MS and isotope dilution. Talanta 2013, 113, 82-92. [CrossRef] [PubMed]

12. Tran, N.H.; Hu, J.; Li, J.; Ong, S.L. Suitability of artificial sweeteners as indicators of raw wastewater contamination in surface water and groundwater. Water Res. 2014, 48, 443-456. [CrossRef] [PubMed]

13. Tran, N.H.; Li, J.; Hu, J.; Ong, S.L. Occurrence and suitability of pharmaceuticals and personal care products as molecular markers for raw wastewater contamination in surface water and groundwater. Environ. Sci. Pollut. Res. 2014, 21, 4727-4740. [CrossRef]

14. Tran, N.H.; Urase, T.; Ta, T.T. A preliminary study on the occurrence of pharmaceutically active compounds in hospital wastewater and surface water in Hanoi, Vietnam. CLEAN-Soil Air Water 2014, 42, 267-275. [CrossRef]

15. Jones, O.A.H.; Voulvoulis, N.; Lester, J.N. Potential ecological and human health risks associated with the presence of pharmaceutically active compounds in the aquatic environment. Crit. Rev. Toxicol. 2004, 34, 335-350. [CrossRef]

16. Lapworth, D.J.; Baran, N.; Stuart, M.E.; Ward, R.S. Emerging organic contaminants in groundwater: A review of sources, fate and occurrence. Environ. Pollut. 2012, 163, 287-303. [CrossRef] [PubMed]

17. Daughton, C.G. Non-regulated water contaminants: Emerging research. EIA Rev. 2004, 24, 711-732. [CrossRef]

18. Richardson, S.D.; Ternes, T.A. Water analysis: Emerging contaminants and current issues. Anal. Chem. 2011, 83, 4614-4648. [CrossRef]

19. Richardson, S.D. Environmental mass spectrometry: Emerging contaminants and current issues. Anal. Chem. 2010, 82, 4742-4774. [CrossRef]

20. Rockstrom, J.; Steffen, W.; Noone, K.; Persson, A.; Chapin, F.S., III; Lambin, E.F.; Lenton, T.M.; Scheffer, M.; Folke, C.; Schellnhuber, H.J.; et al. A safe operating space for humanity: Identifying and quantifying planetary boundaries that must not be transgressed could help prevent human activities from causing unacceptable environmental change, argue Johan Rockstrom and colleagues. Nature 2009, 461, 472-476. [CrossRef]

21. Steffen, W.; Richardson, K.; Rockström, J.; Cornell, S.E.; Fetzer, I.; Bennett, E.M.; Biggs, R.; Carpenter, S.R.; De Vries, W.; De Wit, C.A.; et al. Planetary boundaries: Guiding human development on a changing planet. Science 2015, 347, 6223. [CrossRef] [PubMed]

22. Genena, A.K.; Luiz, D.B.; Gebhardt, W.; Moreira, R.F.; José, H.J.; Schröder, H.F. Imazalil degradation upon applying ozonetransformation products, kinetics, and toxicity of treated aqueous solutions. Ozone Sci. Eng. 2011, 33, 308-328. [CrossRef]

23. Benitez, F.J.; Acero, J.L.; Real, F.J.; Roldan, G.; Rodriguez, E. Photolysis of model emerging contaminants in ultra-pure water: Kinetics, by-products formation and degradation pathways. Water Res. 2013, 47, 870-880. [CrossRef] [PubMed]

24. Escher, B.I.; Fenner, K. Recent advances in environmental risk assessment of transformation products. Environ. Sci. Technol. 2011, 45, 3835-3847. [CrossRef]

25. Baun, A.; Sayre, P.; Steinhäuser, K.G.; Rose, J. Regulatory relevant and reliable methods and data for determining the environmental fate of manufactured nanomaterials. NanoImpact 2017, 8, 1-10. [CrossRef]

26. Krauss, M.; Singer, H.; Hollender, J. LC-high resolution MS in environmental analysis: From target screening to the identification of unknowns. Anal. Bioanal. 2010, 397, 943-951. [CrossRef] [PubMed] 
27. Kind, T.; Fiehn, O. Advances in structure elucidation of small molecules using mass spectrometry. Bioanal. Rev. 2010, 2, 23-60. [CrossRef] [PubMed]

28. Makarov, A.; Denisov, E.; Kholomeev, A.; Balschun, W.; Lange, O.; Strupat, K.; Horning, S. Performance evaluation of a hybrid linear ion trap/orbitrap mass spectrometer. Anal. Chem. 2006, 78, 2113-2120. [CrossRef]

29. National Research Council (US) Committee on Developmental Toxicology. Scientific Frontiers in Developmental Toxicology and Risk Assessment; National Academies Press: Washington, DC, USA, 2000.

30. Meislich, H.; Nechamkin, H.; Sharefkin, J.; Hademenos, G.J. Schaum's Outline of Organic Chemistry; McGraw-Hill Education: Ontario, Canada, 2013.

31. Battaglin, W.A.; Thurman, E.M.; Kalkhoff, S.J.; Porter, S.D. Herbicides and Transformation Products in Surface Waters of the Midwestern United States. J. Am. Water Resour. Assoc. 2003, 39, 743-756. [CrossRef]

32. Baran, N.; Mouvet, C.; Dagnac, T.; Jeannot, R. Infiltration of acetochlor and two of its metabolites in two contrasting soils. J. Environ. Qual. 2004, 33, 241-249. [CrossRef]

33. Hladik, M.L.; Hsiao, J.J.; Roberts, A.L. Are neutral chloroacetamide herbicide degradates of potential environmental concern? Analysis and occurrence in the upper Chesapeake Bay. Environ. Sci. Technol. 2005, 39, 6561-6574. [CrossRef] [PubMed]

34. Miao, X.S.; Yang, J.J.; Metcalfe, C.D. Carbamazepine and its metabolites in wastewater and in biosolids in a municipal wastewater treatment plant. Environ. Sci. Technol. 2005, 39, 7469-7475. [CrossRef] [PubMed]

35. Søeborg, T.; Ingerslev, F.; Halling-Sørensen, B. Chemical stability of chlortetracycline and chlortetracycline degradation products and epimers in soil interstitial water. Chemosphere 2004, 57, 1515-1524. [CrossRef] [PubMed]

36. Bester, K. Fate of triclosan and triclosan-methyl in sewage treatmentplants and surface waters. Arch. Environ. Contam. Toxicol. 2005, 49, 9-17. [CrossRef] [PubMed]

37. Aranami, K.; Readman, J.W. Photolytic degradation of triclosan in freshwater and seawater. Chemosphere 2007, 66, 1052-1056. [CrossRef] [PubMed]

38. Conn, K.E.; Barber, L.B.; Brown, G.K.; Siegrist, R.L. Occurrence and fate of organic contaminants during onsite wastewater treatment. Environ. Sci. Technol. 2006, 40, 7358-7366. [CrossRef]

39. Godfrey, E.; Woessner, W.W.; Benotti, M.J. Pharmaceuticals in on-site sewage effluent and ground water, western Montana. Groundwater 2007, 45, 263-271. [CrossRef]

40. Horii, Y.; Reiner, J.L.; Loganathan, B.G.; Kumar, K.S.; Sajwan, K.; Kannan, K. Occurrence and fate of polycyclic musks in wastewater treatment plants in Kentucky and Georgia, USA. Chemosphere 2007, 68, 2011-2020. [CrossRef]

41. Clara, M.; Strenn, B.; Gans, O.; Martinez, E.; Kreuzinger, N.; Kroiss, H. Removal of selected pharmaceuticals, fragrances and endocrine disrupting compounds in a membrane bioreactor and conventional wastewater treatment plants. Water Res. 2005, 39, 4797-4807. [CrossRef]

42. Glassmeyer, S.T.; Furlong, E.T.; Kolpin, D.W.; Cahill, J.D.; Zaugg, S.D.; Werner, S.L.; Meyer, M.T.; Kryak, D.D. Transport of chemical and microbial compounds from known wastewater discharges: Potential for use as indicators of human fecal contamination. Environ. Sci. Technol. 2005, 39, 5157-5169. [CrossRef]

43. Hanselman, T.A.; Graetz, D.A.; Wilkie, A.C. Manure-borne estrogens as potential environmental contaminants: A review. Environ. Sci. Technol. 2003, 37, 5471-5478. [CrossRef] [PubMed]

44. Hutchins, S.R.; White, M.V.; Hudson, F.M.; Fine, D.D. Analysis of lagoon samples from different concentrated animal feeding operations for estrogens and estrogen conjugates. Environ. Sci. Technol. 2007, 41, 738-744. [CrossRef] [PubMed]

45. Barnes, K.K.; Christenson, S.C.; Kolpin, D.W.; Focazio, M.J.; Furlong, E.T.; Zaugg, S.D.; Meyer, M.T.; Barber, L.B. Pharmaceuticals and other organic waste water contaminants within a leachate plume downgradient of a municipal landfill. Ground Water Monit. Remediat. 2004, 24, 119-126. [CrossRef]

46. Boix, C.; Ibáñez, M.; Sancho, J.V.; Parsons, J.R.; de Voogt, P.; Hernández, F. Biotransformation of pharmaceuticals in surface water and during waste water treatment: Identification and occurrence of transformation products. J. Hazard. Mater. 2016, 302, 175-187. [CrossRef] [PubMed]

47. Göbel, A.; Thomsen, A.; McArdell, C.S.; Joss, A.; Giger, W. Occurrence and sorption behavior of sulfonamides, macrolides, and trimethoprim in activated sludge treatment. Environ. Sci. Technol. 2005, 39, 3981-3989. [CrossRef] [PubMed]

48. Li, D.; Yang, M.; Hu, J.; Ren, L.; Zhang, Y.; Li, K. Determination and fate of oxytetracycline and related compounds in oxytetracycline production wastewater and the receiving river. Environ. Toxicol. Chem. 2008, 27, 80-86. [CrossRef]

49. Kang, D.; Doudrick, K.; Park, N.; Choi, Y.; Kim, K.; Jeon, J. Identification of transformation products to characterize the ability of a natural wetland to degrade synthetic organic pollutants. Water Res. 2020, 187, 116425. [CrossRef]

50. Picó, Y.; Barceló, D. Transformation products of emerging contaminants in the environment and high-resolution mass spectrometry: A new horizon. Anal. Bioanal. 2015, 407, 6257-6273. [CrossRef]

51. Petrovic, M.; Barceló, D. LC-MS for identifying photodegradation products of pharmaceuticals in the environment. Trends Anal. Chem. 2007, 26, 486-493. [CrossRef]

52. Kosjek, T.; Heath, E. Occurrence, fate and determination of cytostatic pharmaceuticals in the environment. Trends Anal. Chem. 2011, 30, 1065-1087. [CrossRef]

53. Speight, J.G.; Speight, J.G. Chemical Transformations in the Environment. In Environmental Organic Chemistry for Engineers; Butterworth-Heinemann: Oxford, UK, 2017; pp. 305-353. 
54. Kolpin, D.W.; Thurman, E.M.; Goolsby, D.A. Occurrence of selected pesticides and their metabolites in near-surface aquifers of the Midwestern United States. Environ. Sci. Technol. 1995, 30, 335-340. [CrossRef]

55. Gooddy, D.C.; Chilton, P.J.; Harrison, I. A field study to assess the degradation and transport of diuron and its metabolites in a calcareous soil. Sci. Total Environ. 2002, 297, 67-83. [CrossRef]

56. Kolpin, D.W.; Furlong, E.T.; Meyer, M.T.; Thurman, E.M.; Zaugg, S.D.; Barber, L.B.; Buxton, H.T. Response to comment on "pharmaceuticals, hormones, and other organic wastewater contaminants in US streams, 1999-2000: A national reconnaissance". Environ. Sci. Technol. 2002, 36, 4007-4008. [CrossRef]

57. Céspedes, R.; Lacorte, S.; Raldúa, D.; Ginebreda, A.; Barceló, D.; Piña, B. Distribution of endocrine disruptors in the Llobregat River basin (Catalonia, NE Spain). Chemosphere 2005, 61, 1710-1719. [CrossRef] [PubMed]

58. Chen, C.Y.; Wen, T.Y.; Wang, G.S.; Cheng, H.W.; Lin, Y.H.; Lien, G.W. Determining estrogenic steroids in Taipei waters and removal in drinking water treatment using high-flow solid-phase extraction and liquid chromatography/tandem mass spectrometry. Sci. Total Environ. 2007, 378, 352-365. [CrossRef]

59. Leusch, F.D.; Neale, P.A.; Busetti, F.; Card, M.; Humpage, A.; Orbell, J.D.; Ridgway, H.F.; Stewart, M.B.; van de Merwe, J.P.; Escher, B.I. Transformation of endocrine disrupting chemicals, pharmaceutical and personal care products during drinking water disinfection. Sci. Total Environ. 2019, 657, 1480-1490. [CrossRef] [PubMed]

60. Hu, X.; Deng, Y.; Zhou, J.; Liu, B.; Yang, A.; Jin, T.; Tsang, Y.F. N-and O self-doped biomass porous carbon cathode in an electro-Fenton system for Chloramphenicol degradation. Sep. Purif. Technol. 2020, 251, 117376. [CrossRef]

61. Shanavas, S.; Priyadharsan, A.; Gkanas, E.I.; Acevedo, R.; Anbarasan, P.M. High efficient catalytic degradation of tetracycline and ibuprofen using visible light driven novel $\mathrm{Cu} / \mathrm{Bi}_{2} \mathrm{Ti}_{2} \mathrm{O}_{7} / \mathrm{rGO}$ nanocomposite: Kinetics, intermediates and mechanism. J. Ind. Eng. Chem. 2019, 72, 512-528.

62. Armstrong, D.L.; Rice, C.P.; Ramirez, M.; Torrents, A. Influence of thermal hydrolysis-anaerobic digestion treatment of wastewater solids on concentrations of triclosan, triclocarban, and their transformation products in biosolids. Chemosphere 2017, 171, 609-616. [CrossRef]

63. Rúa-Gómez, P.C.; Püttmann, W. Occurrence and removal of lidocaine, tramadol, venlafaxine, and their metabolites in German wastewater treatment plants. Environ. Sci. Pollut. Res. 2012, 19, 689-699. [CrossRef]

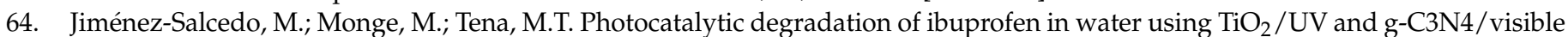
light: Study of intermediate degradation products by liquid chromatography coupled to high-resolution mass spectrometry. Chemosphere 2019, 215, 605-618. [CrossRef]

65. Salma, A.; Thoröe-Boveleth, S.; Schmidt, T.C.; Tuerk, J. Dependence of transformation product formation on pH during photolytic and photocatalytic degradation of ciprofloxacin. J. Hazard. Mater. 2016, 313, 49-59. [CrossRef] [PubMed]

66. Li, L.P.; Wei, D.B.; Du, Y.G. Transformation of ceftriaxone in chlorination process: Products identification and transformation pathways. Environ. Chem. 2013, 32, 1328-1334.

67. Rossini, D.; Ciofi, L.; Ancillotti, C.; Checchini, L.; Bruzzoniti, M.C.; Rivoira, L.; Fibbi, D.; Orlandini, S.; Del Bubba, M. Innovative combination of QuEChERS extraction with on-line solid-phase extract purification and pre-concentration, followed by liquid chromatography-tandem mass spectrometry for the determination of non-steroidal anti-inflammatory drugs and their metabolites in sewage sludge. Anal. Chim. Acta 2016, 935, 269-281.

68. Miao, X.S.; Metcalfe, C.D. Determination of carbamazepine and its metabolites in aqueous samples using liquid chromatographyElectrospray tandem mass spectrometry. Anal. Chem. 2003, 75, 3731-3738. [CrossRef] [PubMed]

69. Rubirola, A.; Llorca, M.; Rodriguez-Mozaz, S.; Casas, N.; Rodriguez-Roda, I.; Barceló, D.; Buttiglieri, G. Characterization of metoprolol biodegradation and its transformation products generated in activated sludge batch experiments and in full scale WWTPs. Water Res. 2014, 63, 21-32. [CrossRef] [PubMed]

70. Liu, R.; Song, S.; Lin, Y.; Ruan, T.; Jiang, G. Occurrence of synthetic phenolic antioxidants and major metabolites in municipal sewage sludge in China. Environ. Sci. Technol. 2015, 49, 2073-2080. [CrossRef] [PubMed]

71. Inami, K.; Mochizuki, M. Oxidative transformation of 2-acetylaminofluorene by a chemical model for cytochrome P450: A water-insoluble porphyrin and tert-butyl hydroperoxide. Bioorg. Med. Chem. 2008, 16, 7070-7077. [CrossRef]

72. Bijlsma, L.; Emke, E.; Hernández, F.; De Voogt, P. Performance of the linear ion trap Orbitrap mass analyzer for qualitative and quantitative analysis of drugs of abuse and relevant metabolites in sewage water. Anal. Chim. Acta 2013, 768, 102-110. [CrossRef] [PubMed]

73. Chen, W.L.; Ling, Y.S.; Lee, D.J.H.; Lin, X.Q.; Chen, Z.Y.; Liao, H.T. Targeted profiling of chlorinated transformation products and the parent micropollutants in the aquatic environment: A comparison between two coastal cities. Chemosphere 2020, 242, 125268. [CrossRef]

74. Jiang, H.; Zhang, D.; Xiao, S.; Geng, C.; Zhang, X. Occurrence and sources of antibiotics and their metabolites in river water, WWTPs, and swine wastewater in Jiulongjiang River basin, south China. Environ. Sci. Pollut. Res. 2013, 20, 9075-9083. [CrossRef] [PubMed]

75. Anari, M.R.; Sanchez, R.I.; Bakhtiar, R.; Franklin, R.B.; Baillie, T.A. Integration of knowledge-based metabolic predictions with liquid chromatography data-dependent tandem mass spectrometry for drug metabolism studies: Application to studies on the biotransformation of indinavir. Anal. Chem. 2004, 76, 823-832. [CrossRef] [PubMed]

76. Testa, B.; Pedretti, A.; Vistoli, G. Reactions and enzymes in the metabolism of drugs and other xenobiotics. Drug Discov. 2012, 17, 549-560. [CrossRef] [PubMed] 
77. Fernandez, M.P.; Ikonomou, M.G.; Buchanan, I. An assessment of estrogenic organic contaminants in Canadian wastewaters. Sci. Total Environ. 2007, 373, 250-269. [CrossRef]

78. McConnell, L.L.; Rice, C.P.; Hapeman, C.J.; Drakeford, L.; Harman-Fetcho, J.A.; Bialek, K.; Fulton, M.H.; Leight, A.K.; Allen, G. Agricultural pesticides and selected degradation products in five tidal regions and the main stem of Chesapeake Bay, USA. Environ. Toxicol Chem. 2007, 26, 2567-2578. [CrossRef] [PubMed]

79. Brooks, B.W.; Chambliss, C.K.; Stanley, J.K.; Ramirez, A.; Banks, K.E.; Johnson, R.D.; Lewis, R.J. Determination of select antidepressants in fish from an effluent-dominated stream. Environ. Toxicol Chem. 2005, 24, 464-469. [CrossRef] [PubMed]

80. Correa-Reyes, G.; Viana, M.T.; Marquez-Rocha, F.J.; Licea, A.F.; Ponce, E.; Vazquez-Duhalt, R. Nonylphenol algal bioaccumulation and its effect through the trophic chain. Chemosphere 2007, 68, 662-670. [CrossRef] [PubMed]

81. Rice, C.P.; Schmitz-Afonso, I.; Loyo-Rosales, J.E.; Link, E.; Thoma, R.; Fay, L.; Altfater, D.; Camp, M.J. Alkylphenol and alkylphenol-ethoxylates in carp, water, and sediment from the Cuyahoga River, Ohio. Environ. Sci. Technol. 2003, 37, 3747-3754. [CrossRef]

82. Meng, Y.; Liu, W.; Liu, X.; Zhang, J.; Peng, M.; Zhang, T. A review on analytical methods for pharmaceutical and personal care products and their transformation products. J. Environ. Sci. 2021, 101, 260-281. [CrossRef]

83. Hug, C.; Ulrich, N.; Schulze, T.; Brack, W.; Krauss, M. Identification of novel micropollutants in wastewater by a combination of suspect and nontarget screening. Environ. Pollut. 2014, 184, 25-32. [CrossRef]

84. Kind, T.; Fiehn, O. Seven Golden Rules for heuristic filtering of molecular formulas obtained by accurate mass spectrometry. BMC Bioinform 2007, 8, 105. [CrossRef] [PubMed]

85. Brown, A.K.; Wong, C.S. Distribution and fate of pharmaceuticals and their metabolite conjugates in a municipal wastewater treatment plant. Water Res. 2018, 144, 774-783. [CrossRef]

86. Fatta-Kassinos, D.; Vasquez, M.I.; Kümmerer, K. Transformation products of pharmaceuticals in surface waters and wastewater formed during photolysis and advanced oxidation processes-degradation, elucidation of byproducts and assessment of their biological potency. Chemosphere 2011, 85, 693-709. [CrossRef] [PubMed]

87. Mompelat, S.; Le Bot, B.; Thomas, O. Occurrence and fate of pharmaceutical products and by-products, from resource to drinking water. Environ. Int. 2009, 35, 803-814. [CrossRef] [PubMed]

88. Bottoni, P.; Caroli, S. Presence of residues and metabolites of pharmaceuticals in environmental compartments, food commodities and workplaces: A review spanning the three-year period 2014-2016. Microchem. J. 2018, 136, 2-24. [CrossRef]

89. Wilkinson, J.; Hooda, P.S.; Barker, J.; Barton, S.; Swinden, J. Occurrence, fate and transformation of emerging contaminants in water: An overarching review of the field. Environ. Pollut. 2017, 231, 954-970. [CrossRef]

90. Choi, Y.; Jeon, J.; Kim, S.D. Identification of biotransformation products of organophosphate ester from various aquatic species by suspect and non-target screening approach. Water Res. 2021, 200, 117201. [CrossRef]

91. Choi, Y.; Jeon, J.; Choi, Y.; Kim, S.D. Characterizing biotransformation products and pathways of the flame retardant triphenyl phosphate in Daphnia magna using non-target screening. Sci. Total Environ. 2020, 708, 135106. [CrossRef]

92. Grabarczyk, Ł.; Mulkiewicz, E.; Stolte, S.; Puckowski, A.; Pazda, M.; Stepnowski, P.; Białk-Bielińska, A. Ecotoxicity screening evaluation of selected pharmaceuticals and their transformation products towards various organisms. Environ. Sci. Pollut. Res. 2020, 27, 26103-26114. [CrossRef]

93. Carbajo, J.B.; Petre, A.L.; Rosal, R.; Herrera, S.; Letón, P.; García-Calvo, E.; Fernández-Alba, A.R.; Perdigón-Melón, J.A. Continuous ozonation treatment of ofloxacin: Transformation products, water matrix effect and aquatic toxicity. J. Hazard. Mater. 2015, 292, 34-43. [CrossRef]

94. Celma, A.; Sancho, J.V.; Salgueiro-González, N.; Castiglioni, S.; Zuccato, E.; Hernández, F.; Bijlsma, L. Simultaneous determination of new psychoactive substances and illicit drugs in sewage: Potential of micro-liquid chromatography tandem mass spectrometry in wastewater-based epidemiology. J. Chromatogr. A 2019, 1602, 300-309. [CrossRef] [PubMed]

95. Xu, W.; Sun, Y.; Wang, Q.; Zhao, J.; Wang, J.; Ge, X.; Xie, C.; Zhou, W.; Du, W.; Li, J.; et al. Changes in aerosol chemistry from 2014 to 2016 in winter in Beijing: Insights from high-resolution aerosol mass spectrometry. J. Geophys. Res. Atmos. 2019, 124, 1132-1147. [CrossRef]

96. Zhou, X.; Zeng, D.; Wang, Y.; Tian, H.; Bai, L.; Tan, H.; Du, L. QuEChERS extraction for high performance liquid chromatographic determination of pyrazosulfuron-ethyl in soils. J. Chem. Soc. Pak. 2012, 34, 28.

97. Daniele, G.; Fieu, M.; Joachim, S.; James-Casas, A.; Andres, S.; Baudoin, P.; Bonnard, M.; Bonnard, I.; Geffard, A.; Vulliet, E. Development of a multi-residue analysis of diclofenac and some transformation products in bivalves using QuEChERS extraction and liquid chromatography-tandem mass spectrometry. Application to samples from mesocosm studies. Talanta 2016, 155, 1-7. [CrossRef]

98. Llompart, M.; Celeiro, M.; Dagnac, T. Microwave-assisted extraction of pharmaceuticals, personal care products and industrial contaminants in the environment. Trends Analyt. Chem. 2019, 116, 136-150. [CrossRef]

99. Azzouz, A.; Ballesteros, E. Combined microwave-assisted extraction and continuous solid-phase extraction prior to gas chromatography-mass spectrometry determination of pharmaceuticals, personal care products and hormones in soils, sediments and sludge. Sci. Total Environ. 2012, 419, 208-215. [CrossRef]

100. Madej, K. Microwave-assisted and cloud-point extraction in determination of drugs and other bioactive compounds. Trends Analyt Chem. 2009, 28, 436-446. [CrossRef] 
101. Wang, H.; Zhou, X.; Zhang, Y.; Chen, H.; Li, G.; Xu, Y.; Zhao, Q.; Song, W.; Jin, H.; Ding, L. Dynamic microwave-assisted extraction coupled with salting-out liquid-liquid extraction for determination of steroid hormones in fish tissues. J. Agric. Food Chem. 2012, 60, 10343-10351. [CrossRef]

102. Huerta, B.; Jakimska, A.; Gros, M.; Rodriguez-Mozaz, S.; Barceló, D. Analysis of multi-class pharmaceuticals in fish tissues by ultra-high-performance liquid chromatography tandem mass spectrometry. J. Chromatogr. A 2013, 1288, 63-72. [CrossRef]

103. Saleh, N.M.; Sanagi, M.M. Pressurized liquid extraction of polycyclic aromatic hydrocarbons from soil samples. Pertanika J. Sci. Technol. 2011, 19, 25-32.

104. Li, W.L.; Zhang, Z.F.; Ma, W.L.; Liu, L.Y.; Song, W.W.; Li, Y.F. An evaluation on the intra-day dynamics, seasonal variations and removal of selected pharmaceuticals and personal care products from urban wastewater treatment plants. Sci. Total Environ. 2018, 640, 1139-1147. [CrossRef] [PubMed]

105. Qu, Z.; Bai, X.; Zhang, T.; Yang, Z. Ultrasound-assisted extraction and solid-phase extraction for the simultaneous determination of five amide herbicides in fish samples by gas chromatography with electron capture detection. J. Sep. Sci. 2017, 40, 1142-1149. [CrossRef] [PubMed]

106. Dorival-García, N.; Zafra-Gómez, A.; Camino-Sánchez, F.J.; Navalón, A.; Vílchez, J.L. Analysis of quinolone antibiotic derivatives in sewage sludge samples by liquid chromatography-tandem mass spectrometry: Comparison of the efficiency of three extraction techniques. Talanta 2013, 106, 104-118. [CrossRef] [PubMed]

107. Dekant, W. The role of biotransformation and bioactivation in toxicity. Mol. Clin. Environ. Toxicol. 2009, 99, 57-86.

108. Adams, J.P.; Collis, A.J.; Henderson, R.K.; Sutton, P.W. Biotransformations in small-molecule pharmaceutical development. Pract. Methods Biocatal. Biotransformations 2010, 1-82. [CrossRef]

109. Sinclair, C.J.; Boxall, A.B. Assessing the ecotoxicity of pesticide transformation products. Environ. Sci. Technol. 2003, 37, 4617-4625. [CrossRef]

110. Brandsma, S.H.; Sellström, U.; de Wit, C.A.; de Boer, J.; Leonards, P.E. Dust measurement of two organophosphorus flame retardants, resorcinol bis (diphenylphosphate) (RBDPP) and bisphenol A bis (diphenylphosphate) (BPA-BDPP), used as alternatives for BDE-209. Environ. Sci. Technol. 2013, 47, 14434-14441. [CrossRef]

111. deBethizy, J.D.; Hayes, J.R. Metabolism: A determinant of toxicity. Princ. Methods Toxicol. 1994, 59-100. [CrossRef]

112. Arand, M.; Cronin, A.; Oesch, F.; Mowbray, S.L.; Alwyn Jones, T. The telltale structures of epoxide hydrolases. Drug Metab. Rev. 2003, 35, 365-383. [CrossRef]

113. Arand, M.; Cronin, A.; Adamska, M.; Oesch, F. Epoxide hydrolases: Structure, function, mechanism, and assay. Methods Enzymol 2005, 400, 569-588.

114. Tukey, R.H.; Strassburg, C.P. Human UDP-glucuronosyltransferases: Metabolism, expression, and disease. Annu. Rev. Pharmacol. Toxicol. 2000, 40, 581-616. [CrossRef] [PubMed]

115. Duffel, M.W.; Marshall, A.D.; McPhie, P.; Sharma, V.; Jakoby, W.B. Enzymatic aspects of the phenol (aryl) sulfotransferases. Drug Metab. Rev. 2001, 33, 369-395. [CrossRef] [PubMed]

116. Vogel, C. Prostaglandin H synthases and their importance in chemical toxicity. Curr. Drug Metab. 2000, 1, 391-404. [CrossRef] [PubMed]

117. Ding, T.; Lin, K.; Bao, L.; Yang, M.; Li, J.; Yang, B.; Gan, J. Biouptake, toxicity and biotransformation of triclosan in diatom Cymbella sp. and the influence of humic acid. Environ. Sci. Pollut. 2018, 234, 231-242. [CrossRef] [PubMed]

118. Jeon, J.; Kurth, D.; Hollender, J. Biotransformation pathways of biocides and pharmaceuticals in freshwater crustaceans based on structure elucidation of metabolites using high resolution mass spectrometry. Chem. Res. Toxicol. 2013, 26, 313-324. [CrossRef]

119. Fu, Q.; Fedrizzi, D.; Kosfeld, V.; Schlechtriem, C.; Ganz, V.; Derrer, S.; Rentsch, D.; Hollender, J. Biotransformation changes bioaccumulation and toxicity of diclofenac in aquatic organisms. Environ. Sci. Technol. 2020, 54, 4400-4408. [CrossRef]

120. Jeon, J.; Hollender, J. In vitro biotransformation of pharmaceuticals and pesticides by trout liver S9 in the presence and absence of carbamazepine. Ecotoxicol. Environ. Saf. 2019, 183, 109513. [CrossRef]

121. Zhu, Y.; Jia, Y.; Liu, M.; Yang, L.; Yi, S.; Feng, X.; Zhu, L. Mechanisms for tissue-specific accumulation and phase I/II transformation of 6: 2 fluorotelomer phosphate diester in earthworm (M. guillelmi). Environ. Int. 2021, 151, 106451. [CrossRef]

122. Abdallah, M.A.E.; Nguyen, K.H.; Moehring, T.; Harrad, S. First insight into human extrahepatic metabolism of flame retardants: Biotransformation of EH-TBB and Firemaster-550 components by human skin subcellular fractions. Chemosphere 2019, 227, 1-8. [CrossRef]

123. Di Giulio, R.T.; Hinton, D.E. The Toxicology of Fishes; CRC Press: Boca Raton, FL, USA, 2008.

124. Rodd, A.L.; Messier, N.J.; Vaslet, C.A.; Kane, A.B. A 3D fish liver model for aquatic toxicology: Morphological changes and Cyp1a induction in PLHC-1 microtissues after repeated benzo (a) pyrene exposures. Aquat. Toxicol. 2017, 186, 134-144. [CrossRef]

125. Santana, M.S.; Sandrini-Neto, L.; Neto, F.F.; Ribeiro, C.A.O.; Di Domenico, M.; Prodocimo, M.M. Biomarker responses in fish exposed to polycyclic aromatic hydrocarbons (PAHs): Systematic review and meta-analysis. Environ. Pollut. 2018, 242, 449-461. [CrossRef]

126. Vieweg, I.; Benedetti, M.; Lanzoni, I.; Regoli, F.; Nahrgang, J. Antioxidant defenses in polar cod (Boreogadus saida) and responsiveness toward dietary crude oil exposure. Mar. Environ. Res. 2017, 130, 48-59. [CrossRef]

127. Banni, M.; Bouraoui, Z.; Ghedira, J.; Clerandeau, C.; Guerbej, H.; Narbonne, J.F.; Boussetta, H. Acute effects of benzo [a] pyrene on liver phase I and II enzymes, and DNA damage on sea bream Sparus aurata. Fish Physiol. Biochem. 2009, 35, 293-299. [CrossRef] [PubMed] 
128. Donner, E.; Kosjek, T.; Qualmann, S.; Kusk, K.O.; Heath, E.; Revitt, D.M.; Ledin, A.; Andersen, H.R. Ecotoxicity of carbamazepine and its UV photolysis transformation products. Sci. Total Environ. 2013, 443, 870-876. [CrossRef]

129. Boillot, C.; Bueno, M.M.; Munaron, D.; Le Dreau, M.; Mathieu, O.; David, A.; Fenet, H.; Casellas, C.; Gomez, E. In vivo exposure of marine mussels to carbamazepine and 10-hydroxy-10, 11-dihydro-carbamazepine: Bioconcentration and metabolization. Sci. Total Environ. 2015, 532, 564-570. [CrossRef] [PubMed]

130. Valdés, M.E.; Huerta, B.; Wunderlin, D.A.; Bistoni, M.A.; Barceló, D.; Rodriguez-Mozaz, S. Bioaccumulation and bioconcentration of carbamazepine and other pharmaceuticals in fish under field and controlled laboratory experiments. Evidences of carbamazepine metabolization by fish. Sci. Total Environ. 2016, 557, 58-67. [CrossRef] [PubMed]

131. Liu, Q.T.; Williams, T.D.; Cumming, R.I.; Holm, G.; Hetheridge, M.J.; Murray-Smith, R. Comparative aquatic toxicity of propranolol and its photodegraded mixtures: Algae and rotifer screening. Environ. Toxicol. Chem. 2009, 28, 2622-2631. [CrossRef]

132. Toolaram, A.P.; Menz, J.; Rastogi, T.; Leder, C.; Kümmerer, K.; Schneider, M. Hazard screening of photo-transformation products from pharmaceuticals: Application to selective $\beta 1$-blockers atenolol and metoprolol. Sci. Total Environ. 2017, 579, 1769-1780. [CrossRef] 